NATIONAL LABORATORY

MANAGED BY UT-BATTELLE FOR THE DEPARTMENT OF ENERGY
Materials Science and Technology Division

CRADA Final Report

For

CRADA Number ORNL02-0644

\section{MATERIALS DEVELOPMENT FOR PULP AND PAPER MILLS, TASK 9 PROOF OF COMMERCIAL CONCEPT: COMMODITY CARBON FIBERS FROM WEYERHAEUSER LIGNIN BASED FIBERS}

F. L. Paulauskas, A. K. Naskar, S. Ozcan, J. R. Keiser Oak Ridge National Laboratory

J. Peter Gorog

Weyerhaeuser Corporation
Prepared by

Oak Ridge National Laboratory

Oak Ridge, TN 37831

managed by

UT-BATTELE, LLC

for the

U.S. Department of Energy

under contract DE-AC05-00OR2225

Approved for

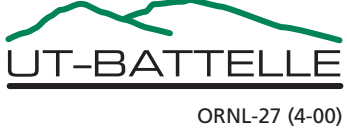

Public Release 


\section{DOCUMENT AVAILABILITY}

Reports produced after January 1, 1996, are generally available free via the U.S. Department of Energy (DOE) Information Bridge.

Web site http://www.osti.gov/bridge

Reports produced before January 1, 1996, may be purchased by members of the public from the following source.

National Technical Information Service

5285 Port Royal Road

Springfield, VA 22161

Telephone 703-605-6000 (1-800-553-6847)

TDD 703-487-4639

Fax 703-605-6900

E-mail info@ntis.fedworld.gov

Web site http://www.ntis.gov/support/ordernowabout.htm

Reports are available to DOE employees, DOE contractors, Energy Technology Data Exchange (ETDE) representatives, and International Nuclear Information System (INIS)

representatives from the following source.

Office of Scientific and Technical Information

P.O. Box 62

Oak Ridge, TN 37831

Telephone 865-576-8401

Fax 865-576-5728

E-mail reports@adonis.osti.gov

Web site http://www.osti.gov/contact.html

This report was prepared as an account of work sponsored by an agency of the United States Government. Neither the United States Government nor any agency thereof, nor any of their employees, makes any warranty, express or implied, or assumes any legal liability or responsibility for the accuracy, completeness, or usefulness of any information, apparatus, product, or process disclosed, or represents that its use would not infringe privately owned rights. Reference herein to any specific commercial product, process, or service by trade name, trademark, manufacturer, or otherwise, does not necessarily constitute or imply its endorsement, recommendation, or favoring by the United States Government or any agency thereof. The views and opinions of authors expressed herein do not necessarily state or reflect those of the United States Government or any agency thereof. 


\section{CRADA FINAL REPORT}

FOR CRADA NO. ORNL02-0644

\section{MATERIALS DEVELOPMENT FOR PULP AND PAPER MILLS, TASK 9 PROOF OF COMMERCIAL CONCEPT: COMMODITY CARBON FIBERS FROM WEYERHAEUSER LIGNIN BASED FIBERS}

\section{Between}

\section{UT-Battelle, LLC}

And

Weyerhaeuser Corporation 
From: Bissett, Paul [paul.bissett@weyerhaeuser.com]

Sent: $\quad$ Friday, August 13, 2010 2:35 PM

To: $\quad$ Eberle, Cliff

Cc: $\quad$ Keiser, James R.; Phillips, Jeanne R.

Subject: $\quad$ RE: Weyerhaeuser CRADA Title

Attachments: Bissett, Paul.vcf

Cliff,

We have reviewed the document and approve the content for public release. No modifications are necessary.

Thanks,

Paul Bissett

WTC $1 \mathrm{H} 2$

Tel: (253) 928-6733

Tel: (253) 924-6528

Cell: (253) 394-1018

Fax: (253) 924-6603

paul.bissett@weyerhaeuser.com 


\section{Background}

Tasks were assigned to Oak Ridge National Laboratory (ORNL) researchers for the development of lignin-based carbon fiber from a specific precursor that was produced by the Participant (Weyerhaeuser Corporation). These tasks included characterization of precursor polymers and fibers; and the development of conversion parameters for the fibers. ORNL researchers provided recommendations for in-house characterization of the precursor at the participant's laboratory.

During the early stage of the precursor fiber production trials of various spools of fibers with varied compositions were produced. Some of those samples were sent to ORNL (by the Participant) for the development of conversion protocol. The trial tow samples were oxidized at ORNL's precursor evaluation system (PES), a bench-scale facility consisting of an oven, filament winder, tension controller, and a let off creel. The PES is a modular tool useful for the development of precursor conversion protocol. It can handle a single filament to a large single tow (50k filaments). It can also offer precise tensioning for fewfilament tows. In the PES, after oxidation, fibers are typically carbonized first at low temperature, $\leq 600^{\circ} \mathrm{C}$, and subsequently at a higher temperature, $\leq 1200^{\circ} \mathrm{C}$ with controlled residence time. ORNL has recently installed a new carbonization furnace with $1700^{\circ} \mathrm{C}$ limit and a furnace with $2500^{\circ} \mathrm{C}$ capacity is under installation.

\section{Summary}

A protocol for the oxidation and carbonization of the trial precursor fibers was developed. Oxidized fiber with a density of $1.46 \mathrm{~g} / \mathrm{cc}$ (oxidation time: $90 \mathrm{~min}$ ) shows qualitative flame retardancy via simple flame test (fibers do not catch fire or shrink when exposed to flame). Oxidized and carbonized filaments of the Weyerhaeuser precursor fibers show moderate mechanical properties and $47-51 \%$ carbon yield (based on oxidized fiber mass) after carbonization between $1000^{\circ}-1400^{\circ} \mathrm{C}$. The properties of fibers from nonoptimized composition and processing parameters indicate the potential of low-cost, lowend carbon fibers based on renewable resource materials. Further work is necessary to produce high quality precursor and the corresponding carbonized filaments of superior properties. 